\title{
HUBUNGAN KARAKTERISTIK PREDISPOSING DENGAN KUNJUNGAN PELAYANAN VOLUNTARY COUNSELLING AND TESTING (VCT) ULANG PADA WARIA
}

\author{
${ }^{1}$ Ahmad Kusnaeni \\ ${ }^{1}$ Stikes Al-irsyad Al-Islamiyyah Cilacap \\ ahmadkusnaeni@Gmail.com
}

\begin{abstract}
ABSTRAK
Latar belakang penelitian ini adalah waria atau waria yang rentan terhadap HIV, hal ini disebabkan oleh banyak waria yang terkait dengan tindakan berisiko seperti penggunaan kondom yang tidak konsisten dan menggunakan obat-obatan atau alkohol. Tingginya jumlah IMS dan HIV terjadi pada transeksual. Deteksi dini, pencegahan HIV / AIDS dengan mengunjungi VCT terkait dengan perilaku transeksual dalam menggunakan layanan kesehatan. Penelitian ini bertujuan untuk menganalisis karakteristik predisposisi kunjungan layanan VCT berulang kali ke transeksual. Metode penelitian menggunakan survei analitik, waktu penelitian dengan cross sectional. Teknik analisis menggunakan chi square. Data diambil dengan memberikan kuesioner kepada 135 waria yang tergabung dalam IWACI dengan melakukan total sampling. Hasil penelitian menyatakan bahwa karakteristik predisposisi yang berhubungan dengan kunjungan layanan VCT berulang kali ke transeksual di Cilacap adalah tentang riwayat infeksi $(p=0,036)$, persepsi terhadap layanan VCT ( $p$ $=0,000)$, persepsi terhadap perilaku seksual $(\mathrm{p}=0,0005)$, dan dukungan kelompok $(\mathrm{p}=0,008)$. Faktor usia $(\mathrm{p}=0078)$. Pendidikan $(\mathrm{p}=0,776)$, ekonomi sosial $(\mathrm{p}=0,731)$, pengetahuan tentang VCT $(p=0,054)$ VCT sebagai gerbang penting untuk pencegahan dan pengobatan HIV, dapat meningkatkan berulang kali cakupan VCT ke transeksual dengan meningkatkan layanan yang lebih baik dan kemanusiaan, dan juga mengubah persepsi negatif transeksual ke layanan VCT dengan pendekatan pribadi.
\end{abstract}

Kata kunci: karakteristik predisposisi, layanan VCT berulang, transeksual.

\section{PREDISPOSING CARACTERISTIC RELATED TO VISITING OF VOLUNTARY COUNSELLING AND TESTING VCT SERVICE REPEATEDLY TO TRANSEXUAL}

\begin{abstract}
This research's background is transgender or transexual who susceptable to HIV, it caused by many transgender related to risk action such as the use of unconsistent condom and using drugs or alcohol. The high number of IMS and HIV happened to the transexual. Early detection, the prevention of HIV/AIDS by visiting VCT is related to the transexualbehaviour in using health service. This research aims to analyse predisposing caracteristic the visiting of VCT service repeatedly to the transexual. The research method used analitic survey, time research by cross sectional. The analysis technic used chi square. The data is took by giving quesioner to 135 transexuals who belongs to IWACI by doing total sampling. The research result stated that predisposing caracteristic which related to visiting of VCT service repeatedly to transexual in Cilacap is about infection history $(p=0,036)$, perception to the service of VCT $(p=0,000)$, perception to the sexual behaviour $(p=0,0005)$, and group's support $(p=0,008)$. The age factor $(p=0078)$. Education $(p=0,776)$, social economy $(p=0,731)$, knowledge about VCT $(p=0,054)$ VCT as the important gate to prevent and treatment of HIV, it can increase repeatedly VCT scope to the transexual by increasing the better service and humanity, and also changing the transexual negative perception to the VCT service by personal approach.
\end{abstract}

Keywords: predisposing caracteristic, repeatedly VCT service, transexual. 


\section{PENDAHULUAN}

Perkembangan permasalahan Human Immunodeficience Virus (HIV/AIDS) semakin lama semakin mengkhawatirkan baik dari sisi kuantitatif maupun kualitatif. Secara global, diperkirakan rata-rata $35,3(32,2-38,8)$ juta orang yang hidup dengan HIV di tahun 2012. Peningkatan dari tahun-tahun sebelumnya karena lebih banyak orang menerima kehidupan. Antiretroviral therapy or treatment (ART). Ada rata-rata 2,3 (1,9-2,7) juta infeksi HIV baru secara global, menunjukkan penurunan $33 \%$ dalam jumlah infeksi baru dari rata-rata 3,4 (3,1-3,7) juta 2001. Pada saat yang sama jumlah kematian AIDS juga menurun dengan rata-rata 1,6 (1,41,9) juta AIDS kematian pada tahun 2012, turun dari rata-rata $2,3(2,1-2,6)$ juta pada tahun 2005. Jumlah infeksi HIV baru pertahun pada orang dewasa dan remaja menurun 50\% atau lebih di 26 negara antara 2001 sampai 2012. Namun, negara-negara lain yang tidak mengintensifkan upaya pencegahan penularan HIV seksual, prevalensinya masih relatif tinggi. Populasi kunci yang berisiko tinggi HIV diantaranya adalah pekerja seks, laki-laki yang berhubungan seks dengan laki-laki (LSL), transgender dan pengguna narkoba (UNAIDS, 2013).

Perkembangan jumlah kasus baru HIV positif di Indonesia pada tahun 2013 kembali mengalami peningkatan secara signifikan. Setelah tiga tahun berturut-turut (2010-2012) cukup stabil, pada tahun 2013 dengan kenaikan mencapai $35 \%$ dibanding tahun 2012. Lebih dari dua per lima provinsi (14 provinsi) di Indonesia memiliki jumlah kasus HIV lebih dari 440 kasus, meliputi seluruh provinsi di Pulau Papua dan Pulau Jawa Bali serta beberapa provinsi di Sumatera, Kalimantan, dan Sulawesi. Jumlah kasus HIV pada kelompok tersebut menyumbang hampir 90\% dari seluruh jumlah kasus HIV di Indonesia. Provinsi dengan jumlah HIV tertinggi yaitu DKI Jakarta, Papua, dan Jawa Timur (Kemenkes, 2014).

Transgender merupakan istilah umum yang digunakan untuk menggambarkan orang yang identitas gender (rasa diri mereka sebagai laki-laki atau perempuan) atau ekspresi jenis kelamin berbeda dari seks kelahiran mereka. Secara garis besar, siapa pun yang identitasnya, penampilan, atau perilaku ada di luar dari norma gender yang konvensional dapat digambarkan sebagai transgender. Namun, tidak semua orang yang penampilannya atau perilakunya berbeda dengan tipe gender tertentu akan mengidentifikasi sebagai orang transgender (American Psychological Association, 2006).

Transgender rentan terhadap HIV, hal ini disebabkan banyak individu transgender yang terkait dengan perilaku berisiko seperti penggunaan kondom yang tidak konsisten dan penggunaan lebih besar dari obat-obatan atau alkohol (UNAIDS, 2014). Data surveilans di negara-negara miskin dan menengah menemukan bahwa pria yang berhubungan seks dengan laki-laki 19,3 kali lebih mungkin untuk hidup dengan HIV dibandingkan pria heteroseksual. Di seluruh dunia, LSL membawa beban berat dari penyakit HIV. Tingkat prevalensi HIV di kalangan LSL di Timur Tengah dan Afrika Utara diperkirakan terendah 3,0\% dan tertinggi 25,4. Di Utara, Selatan, dan Amerika Tengah, Selatan dan Asia Tenggara dan Sub-Sahara Afrika, prevalensi HIV rata-rata dalam kisaran 1418\% (International AIDS Society, 2014).

Perilaku seksual pada waria (transgender lakilaki) di Indonesia cenderung berisiko dan tingkat prevalensi HIV yang tinggi. Data surveilans memperlihatkan temuan-temuan kunci dari Surveilans Biologis Perilaku Terpadu pada Kelompok Berisiko (STBP) 2007 untuk waria dari lima kota (Jakarta, Bandung, Semarang, Surabaya dan Malang). Data perilaku dikumpulkan di kelima kota tersebut. Sedangkan data biologis dikumpulkan di tiga kota (Jakarta, Bandung dan Surabaya). Estimasi Depkes memperkirakan terdapat sekitar 20.960 hingga 35.300 waria di Indonesia pada tahun 2006. Hasil STBP dari Jakarta dan Bandung menunjukkan adanya prevalensi Infeksi Menular Seksual (IMS) dan HIV yang tinggi di kalangan waria. Prevalensi HIV berkisar dari $14 \%$ di Bandung hingga $34 \%$ di Jakarta (STBP 2007).

Angka kejadian IMS yang tinggi dan kejadian HIV meningkat pada waria. Meskipun jumlah waria di Indonesia tidak besar, hal ini disebabkan karena pelanggan atau klien utamanya adalah pria muda yang mejadi penghubung potensial ke populasi umum, sehingga waria memiliki potensi untuk memberikan dampak besar terhadap epidemi HIV/AIDS di Indonesia. Tingkat pendidikan umumnya rendah pada waria, pemberian 
informasi secara sederhana dan mudah dipahami merupakan hal yang sangat penting. Maka perlu dilakukan peningkatan kualitas dalam hal konseling HIV dan mobilisasi komunitas waria untuk datang ke Puskesmas atau Rumah Sakit untuk mendapat layanan IMS dan konseling dan tes HIV melalui Voluntary Counselling and Testing (VCT)(STBP 2007).

VCT merupakan pintu masuk penting untuk pencegahan dan perawatan HIV. VCT merupakan proses konseling pra testing, konseling post testing, dan testing HIV secara sukarela yang bersifat confidential dan secara lebih dini membantu orang mengetahui status HIV. Konseling pra testing memberikan pengetahuan tentang HIV dan manfaat testing, pengambilan keputusan untuk testing, dan perencanaan atas issue HIV yang akan dihadapi. Konseling post testing membantu seseorang untuk mengerti dan menerima status $(\mathrm{HIV}+)$ dan merujuk pada layanan dukungan. VCT merupakan pintu masuk penting untuk pencegahan dan perawatan HIV. Tes HIV adalah pemeriksaan terhadap antibodi yang terbentuk akibat masuknya HIV kedalam tubuh, atau pemeriksaan antigen yang mendeteksi adanya virus itu sendiri atau komponennya, Prosedur pemeriksaan tes HIV sesuai dengan panduan Nasional yang berlaku pada saat ini, Untuk pemeriksaan pertama biasanya digunakan tes cepat (Rapid Diagnostic Test) dengan sensitifitas yang cukup tinggi, sedang untuk pemeriksaan selanjutnya digunakan tes kit dengan spesifitas yang lebih tinggi. Antibodi biasanya baru terdeteksi sejak 2 minggu hingga 3 bulan setelah terinfeksi HIV. Masa tersebut disebut masa jendela (windows period). Oleh karena itu bila hasil tes HIV negatif yang dilakukan dalam masa 3 bulan setelah kemungkinan terinfeksi, perlu dilakukan tes ulang, Tes ulang merupakan tes HIV pada orang yang pernah melakukan tes sebelumnya dan memperoleh hasilnya, terlebih bila masih terus terdapat perilaku yang berisiko seperti sex yang tidak terlindung pada pasien IMS, para penjaja seks dan pelanggannya, LSL dan pasangan ODHA, dan pemakaian alat suntik secara bersamaan di antara para pengguna napza suntikan (Pedoman Nasional Terapi Antiretroviral tahun 2007)

Menurut Alemie dan Balcha, (2012) pentingnya pemanfaatan layanan klinik VCT dikarenakan entry point yang sudah diakui secara internasional dan merupakan cara yang efektif dalam pencegahan dan perawatan HIV dan AIDS. Dengan mengetahui status HIV secara dini dimungkinkan melakukan pemanfaatan layanan terkait preventif, promotif, kuratif, rehabilitatif sehingga hal ini sangat penting dalam memanfaatkan layanan VCT yang bisa dilakukan di Puskesmas maupun di Rumah Sakit. Perawat komunitas pada Vulnerable population waria di tuntut untuk mendorong waria yang mengidap penyakit menular seks (PMS) seperti HIV AIDS untuk mau mengikuti dan patuh terhadap program pengobatan Anti Retro Viral (ART). Pendidikan kesehatan kepada waria dengan HIV AIDS dan keluarga dilakukan sebagai upaya untuk mencegah infeksi oportunistik terulang dan melihara stabilitas waria dengan HIV AIDS (Allender \& Spradley, 2005)

Berdasarkan data dari Ikatan Waria Cilacap (IWACI), jumlah waria yang tergabung sejumlah 208 orang sedangkan yang aktif tergabung dalam IWACI sampai dengan Tahun 2017 adalah 135 orang. Sebagai salah satu kelompok yang mempunyai perilaku seksual berisiko, sampai saat ini jumlah waria yang sudah melakukan kunjungan VCT hanya sekitar 135 orang.

Deteksi dini, pencegahan HIV/AIDS dengan melakukan kunjungan VCT sangat bergantung pada perilaku waria dalam pemanfaatan pelayanan kesehatan. Anderson (1974) menyatakan bahwa pemanfaatan pelayanan kesehatan dibagi menjadi 3 yaitu : 1) karakteristik predisposing seperti umur dan jenis kelamin, tingkat pendidikan, pekerjaan, kesukuan atau ras, dan keyakinan bahwa pelayanan kesehatan dapat menolong proses penyembuhan penyakit. Hasil penelitian Puljic et. al (2014) menemukan bahwa MSM yang mengidentifikasi diri sebagai beresiko tinggi infeksi berhubungan dengan test HIV ulang di antara pria yang berhubungan seks dengan laki-laki di Kroasia. Tsegay, Edris dan Meseret (2013) menemukkan bahwa faktorfaktor utama yang diidentifikasi untuk meningkatkan pemanfaatan layanan VCT meliputi pengetahuan tentang VCT, informasi tentang kerahasiaan, tidak adanya stigma yang dirasakan, persepsi risiko yang lebih tinggi dan pengetahuan tentang HIV.

Berdasarkan hal tersebut peneliti tertarik untuk melakukan penelitian dengan judul 
"Hubungan karakteristik predisposing dengan kunjungan pelayanan VCT ulang pada waria"

\section{METODE}

Jenis penelitian ini adalah penelitian kuantitatif dengan desain survei analitik dengan pendekatan waktu cross sectional
Sampel dalam penelitian ini merupakan waria yang sudah melakukan kunjungan VCT. Jumlah sampel yang diambil dalam penelitian ini adalah seluruh anggota populasi yang memenuhi kriteria inklusi yaitu sejumlah seratus tiga puluh lima (135) orang. Teknik analisis menggunakan Chi-Square menggunakan taraf signifikansi 5\% $(\alpha=0,05)$

HASIL

Karakteristik Responden

Tabel 1.

Data Demografi $(\mathrm{n}=135$ responden $)$

\begin{tabular}{clcc}
\hline No. & Demografi & Frekuensi (n) & $\begin{array}{c}\text { Persentase } \\
(\%)\end{array}$ \\
\hline 1. & Umur & & \\
& $20-40$ tahun & 11 & 8,1 \\
& $41-60$ tahun & 124 & 91,9 \\
2. & Pendidikan & & \\
& SD & 16 & 11,9 \\
& SMP & 78 & 57,8 \\
& SMA & 41 & 30,4 \\
3. & Penghasilan & & \\
& < 1,5 juta & 80 & 59,3 \\
& 1,5-3 juta & 48 & 35,6 \\
& $3-4,5$ juta & 7 & 5,2 \\
\hline & Jumlah & 135 & 100,0 \\
\hline
\end{tabular}

Hasil penelitian menunjukkan bahwa sebagian besar waria berusia dewasa akhir (41 - 60 tahun) $(91,9 \%)$, berpendidikan lulus SMP
$(57,8 \%)$, dan memiliki penghasilan $<1,5$ juta per bulan $(59,3 \%)$.

Tabel 2.

Distribusi Frekuensi dan Persentase Kunjungan pelayanan VCT ulang pada Waria $(\mathrm{n}=135)$

\begin{tabular}{llcc}
\hline No. & \multicolumn{1}{c}{ Variabel } & Frekuensi (n) & $\begin{array}{c}\text { Persentase } \\
(\%)\end{array}$ \\
\hline 1. & Riwayat VCT & & \\
a. Pengetahuan Umum VCT & 13 & 9,6 \\
Salah & & 122 & 90,4 \\
Benar & & \\
b. Pengetahuan Tujuan VCT & 40 & 29,6 \\
Salah & & 95 & 70,4 \\
Benar & & \\
c. Pengetahuan Manfaat VCT & 66 & 48,9 \\
Salah & & 69 & 51,1 \\
Benar & & \\
d. Pelaksanaan Testing HIV di VCT & 0 & 0,0 \\
Tidak pernah & 135 & 100,0 \\
Pernah & & \\
e. Jumlah Kunjungan VCT & 65 & 48,1 \\
1 & 24 & 17,8 \\
2 & 34 & 25,2 \\
\hline
\end{tabular}




\begin{tabular}{llcc}
\hline No. & \multicolumn{1}{c}{ Variabel } & Frekuensi (n) & $\begin{array}{c}\text { Persentase } \\
(\%)\end{array}$ \\
\hline $4 \quad$ Jarak VCT ke-1 dengan VCT ke-2 & 12 & 8,9 \\
f. & & 48,1 \\
0 bulan (tidak pasti / hanya melakukan 1) & 65 & 0,0 \\
1 bulan & 0 & 0,0 \\
2 bulan & 0 & 51,9 \\
3 bulan & 70 & 0,0 \\
4 bulan & 0 & 48,1 \\
g. Jarak VCT ke-2 dengan VCT ke-3 & & 0,0 \\
0 bulan (tidak pasti / hanya melakukan 1) & 65 & 0,7 \\
1 bulan & 0 & 50,4 \\
2 bulan & 1 & 0,7 \\
3 bulan & 68 & \\
4 bulan & 1 & 48,1 \\
Kunjungan pelayanan VCT ulang & & 51,9 \\
\hline Tidak VCT ulang & 65 & 100,0 \\
VCT ulang & 70 & \\
\hline Jumlah & 135 & \\
\hline
\end{tabular}

Hasil penelitian menunjukkan bahwa sebagian besar waria di Kabupaten Cilacap dapat menjawab dengan benar pengetahuan umum tentang VCT $(90,4 \%)$, dapat menjawab dengan benar tentang tujuan VCT $(70,4 \%)$, dapat menjawab dengan benar tentang manfaat VCT $(51,1 \%)$, semuanya sudah pernah melakukan testing HIV dan paling banyak melakukan kunjungan VCT sebanyak 1 kali $(48,1 \%)$. Sedangkan untuk kunjungan pelayanan VCT ulang terlihat waria yang melakukan VCT ulang (51,9\%), sedikit lebih banyak dari yang tidak melakukan VCT ulang $(48,1 \%)$.

Tabel 3.

Karakteristik Predisposing Kunjungan pelayanan VCT ulang pada Waria $(\mathrm{n}=135)$

\begin{tabular}{clcc}
\hline No. & \multicolumn{1}{c}{ Variabel } & Frekuensi (n) & $\begin{array}{c}\text { Persentase } \\
(\%)\end{array}$ \\
\hline 1. & Umur & 11 & 8,1 \\
& $\begin{array}{l}\text { Dewasa awal }(20-40 \text { tahun }) \\
\text { Dewasa akhir }(41-60 \text { tahun })\end{array}$ & 124 & 91,9 \\
2. & Pendidikan & 94 & 69,6 \\
& Dasar & 41 & 30,4 \\
& Menengah & & \\
3. & Sosial ekonomi & 80 & 59,3 \\
& Rendah & 55 & 40,7 \\
Tinggi & & \\
4. & 80 & 59,3 \\
& Tiwayat infeksi & 55 & 40,7 \\
Ada riwayat & & 11,9 \\
5. Pengetahuan tentang VCT & 16 & 59,3 \\
& Kurang & 80 & 28,9 \\
& Cukup & 39 & 45,2 \\
Baik & Persepsi terhadap Pelayanan VCT & & 54,8 \\
\hline Negatif & 61 & 100,0 \\
\hline
\end{tabular}


Hasil penelitian menunjukkan bahwa sebagian besar waria di Cilacap berusia dewasa akhir (41 - 60 tahun) $(91,9 \%)$, berpendidikan dasar atau hanya lulus SD dan SMP $(69,6 \%)$, memiliki sosial ekonomi yang rendah
$(59,3 \%)$, tidak ada riwayat infeksi penyakit menular seksual (59,3\%), memiliki pengetahuan yang cukup tentang VCT $(59,3 \%)$, dan memiliki persepsi yang positif terhadap pelayanan $\mathrm{VCT}(54,8 \%)$.

Tabel 3.

Hubungan faktor predisposing dengan Kunjungan pelayanan VCT ulang pada Waria $(\mathrm{n}=135)$

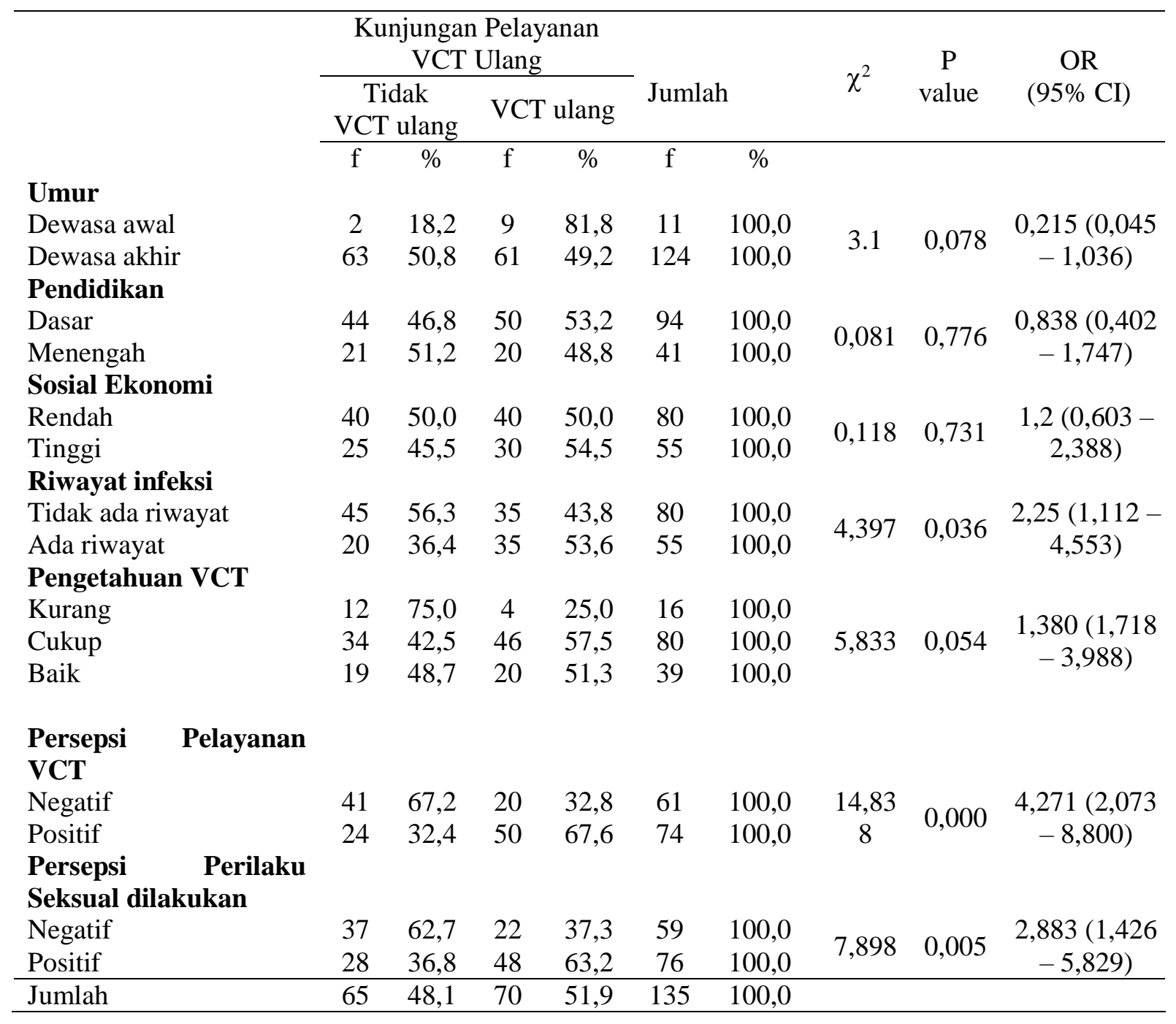

Hasil penelitian menunjukkan bahwa proporsi waria yang melakukan kunjungan VCT ulang lebih banyak pada waria yang berumur dewasa awal $(81,8 \%)$ dibandingkan dengan yang berumur dewasa akhir $(49,2 \%)$. Hasil uji Chi Square didapatkan nilai $\mathrm{p}=0,078$, maka tidak terdapat hubungan antara umur waria dengan kunjungan pelayanan VCT ulang. Proporsi waria yang melakukan kunjungan VCT ulang pada waria yang berpendidikan dasar $(53,2 \%)$ tidak jauh berbeda dengan yang berpendidikan menengah $(53,2 \%)$. Hasil uji chi square didapatkan nilai $\mathrm{p}=0,776$, maka tidak terdapat hubungan antara pendidikan waria dengan kunjungan pelayanan VCT ulang. Proporsi waria yang melakukan kunjungan VCT ulang pada waria dengan sosial ekonomi rendah $(50,0 \%)$ tidak jauh berbeda dengan sosial ekonomi tinggi $(54,5 \%)$. Hasil uji Chi Square didapatkan nilai $\mathrm{p}$ $=0,731$, maka tidak terdapat hubungan antara sosial ekonomi waria dengan kunjungan pelayanan VCT ulang.

Proporsi waria yang melakukan kunjungan VCT ulang lebih banyak pada waria yang ada riwayat infeksi penyakit menular seksual $(53,6 \%)$ dibandingkan dengan yang tidak ada riwayat infeksi $(43,8 \%)$. Hasil uji chi square didapatkan nilai $\mathrm{p}=0,036$, maka terdapat hubungan riwayat 
infeksi penyakit menular seksual waria dengan kunjungan pelayanan VCT ulang. Proporsi waria yang melakukan kunjungan VCT ulang lebih banyak pada waria dengan pengetahuan tentang VCT cukup $(57,5 \%)$ dan baik $(51,3 \%)$ dibandingkan dengan yang kurang $(25,0 \%)$. Hasil uji Chi Square didapatkan nilai $p=0,054$, maka tidak terdapat hubungan pengetahuan tentang VCT waria dengan kunjungan pelayanan VCT ulang.

Proporsi waria yang melakukan kunjungan VCT ulang lebih banyak pada waria dengan persepsi positif tentang pelayanan VCT $(67,6 \%)$ dibandingkan dengan yang negatif $(32,8 \%)$. Hasil uji chi square didapatkan nilai $\mathrm{p}=0,000$, maka terdapat hubungan antara persepsi terhadap pelayanan VCT waria dengan kunjungan pelayanan VCT ulang. Proporsi waria yang melakukan kunjungan VCT ulang lebih banyak pada waria dengan persepsi positif tentag perilaku seksual yang dilakukan $(63,2 \%)$ dibandingkan dengan yang negatif $(37,3 \%)$. Hasil uji Chi Square didapatkan nilai $p=0,005$, maka terdapat hubungan antara persepsi terhadap perilaku seksual yang dilakukan waria dengan kunjungan pelayanan VCT ulang.

\section{PEMBAHASAN}

Hubungan antara Umur Waria dengan Kunjungan pelayanan VCT ulang

Hasil penelitian menunjukkan bahwa proporsi waria yang melakukan kunjungan VCT ulang lebih banyak pada waria yang berumur dewasa awal (81,8\%) dibandingkan dengan yang berumur dewasa akhir $(49,2 \%)$. Artinya diantara waria anggota IWACI, yang melakukan kunjungan pelayanan VCT ulang lebih banyak pada waria yang berusia dewasa awal. Tidak terdapat hubungan antara faktor umur waria dengan kunjungan pelayanan VCT ulang. Hal ini kemungkinan pada usia dewasa awal waria merasa bahwa masa depannya masih jauh sehingga mempengaruhi keputusan waria untuk melakukan kunjungan VCT ulang untuk memastikan hasil test HIV apakah positif atau negatif, demikian halnya pada waria yang berusia dewasa akhir, mengingat bahwa masih termasuk pada usia produktif maka merasa perlu melakukan kunkungan VCT ulang. Bila dilihat dari proporsi memang terlihat bahwa waria yang berusia dewasa awal lebih banyak yang melakukan kunjungan VCT ulang akan tetapi apabila dilihat secara kuantitatif dari jumlah waria yang tergabung pada IWACI, maka waria yang berusia dewasa akhir lebih banyak yang melakukan kunjungan VCT ulang. Hasil penelitian berbeda dengan hasil penelitian Wimonsate et. Al (2011) bahwa di antara pria yang berhubungan seks dengan laki-laki di Thailand menemukan bahwa laki-laki pekerja seks usia yang lebih tua yang lebih banyak melakukan test HIV ulang, dan umur berhubungan dengan dengan pengujian test HIV ulang

Hubungan antara Pendidikan Waria dengan Kunjungan pelayanan VCT ulang

Hasil penelitian menunjukkan bahwa proporsi waria yang melakukan kunjungan VCT ulang pada waria yang berpendidikan dasar $(53,2 \%)$ tidak jauh berbeda dengan yang berpendidikan menengah $(53,2 \%)$. Hasil uji statistik didapatkan tidak terdapat hubungan antara pendidikan waria dengan kunjungan pelayanan VCT ulang. Hal ini kemungkinan disebabkan pendidikan waria yang relatif homogen sehingga kurang memberikan efek yang berbeda terhadap kunjungan pelayanan VCT ulang.

Hasil penelitian berbeda dengan Anderson dan Newman (1973) yang menyatakan bahwa individu yang tingkat pendidikannya tinggi dapat mengenal tanda-tanda sakit dan akibatnya lebih besar keinginannya untuk mencari pengobatan dan pencegahan terhadap sakit. Individu-individu yang berbeda suku bangsa, pekerjaan, atau tingkat pendidikan mempunyai kecenderungan yang tidak sama dalam mengerti dan bereaksi terhadap kesehatan mereka. Dengan kata lain, pendekatan struktur sosial didasarkan pada asumsi bahwa orang-orang dengan latar belakang struktur sosial yang bertentangan akan menggunakan pelayanan kesehatan dengan cara yang tertentu pula.

Hubungan antara Sosial Ekonomi Waria dengan Kunjungan pelayanan VCT ulang

Proporsi waria yang melakukan kunjungan VCT ulang pada waria dengan sosial ekonomi rendah $(50,0 \%)$ tidak jauh berbeda dengan sosial ekonomi tinggi (54,5\%). Hasil uji statistik didapatkan tidak terdapat hubungan antara faktor sosial ekonomi waria dengan kunjungan pelayanan VCT ulang. Hal ini kemungkinan sosial ekonomi waria yang homogen yaitu pada kategori sosial ekonomi rendah sedangkan kunjungan VCT untuk melakukan test HIV tidak dikenakan biaya sehingga tingkat sosial ekonomi kurang memberikan efek yang berbeda terhadap kunjungan VCT ulang pada waria dengan sosial ekonomi rendah dan tinggi. 
Hasil penelitian berbeda dengan penelitian Wimonsate et. Al (2011) dimana kemampuan responden untuk membayar merupakan pendukung berhubungan dengan pengujian test HIV ulang di antara pria yang berhubungan seks dengan laki-laki. Hasil penelitian juga berbeda dengan Anderson dan Newman (1973) yang menyatakan bahwa individu akan bertindak menggunakan pelayanan kesehatan jika mampu menggunakannya. Penggunaan pelayanan kesehatan yang ada tergantung kemampuan konsumen untuk membayar.

Hubungan antara Riwayat Infeksi Penyakit Menular Seksual Waria dengan Kunjungan pelayanan VCT ulang

Proporsi waria yang melakukan kunjungan VCT ulang lebih banyak pada waria yang ada riwayat infeksi penyakit menular seksual $(53,6 \%)$ dibandingkan dengan yang tidak ada riwayat infeksi $(43,8 \%)$. Hasil uji statistik didapatkan terdapat hubungan antara riwayat infeksi penyakit menular seksual waria dengan kunjungan pelayanan VCT ulang. Hasil penelitian kemungkinan karena transgender rentan terhadap HIV, hal ini disebabkan banyak individu transgender yang terkait dengan perilaku berisiko seperti penggunaan kondom yang tidak konsisten dan penggunaan lebih besar dari obat-obatan atau alkohol. Dari hasil penelitian diketahui bahwa waria yang ada riwayat infeksi penyakit menular seksual ada sebanyak 40,7\% hal ini relevan dengan temuan dari Surveilans Biologis Perilaku Terpadu pada Kelompok Berisiko (STBP) 2007 untuk waria dari lima kota (Jakarta, Bandung, Semarang, Surabaya dan Malang). Data perilaku dikumpulkan di kelima kota tersebut. Sedangkan data biologis dikumpulkan di tiga kota (Jakarta, Bandung dan Surabaya). Estimasi Depkes memperkirakan terdapat sekitar 20.960 hingga 35.300 waria di Indonesia pada tahun 2006. Hasil STBP dari Jakarta dan Bandung menunjukkan adanya prevalensi Infeksi Menular Seksual (IMS) dan HIV yang tinggi di kalangan waria. Prevalensi HIV berkisar dari $14 \%$ di Bandung hingga 34\% di Jakarta.

Hasil penelitian mendukung Wimonsate et. Al (2011) bahwa riwayat infeksi menular seksual merupakan salah satu faktor yang berhubungan dengan pengujian test HIV ulang di antara pria yang berhubungan seks dengan laki-laki di Thailand. Hasil penelitian juga relevan dengan Puljic et. al (2014) yang menemukan bahwa MSM yang mengidentifikasi diri sebagai beresiko tinggi infeksi berhubungan dengan test
HIV ulang di antara pria yang berhubungan seks dengan laki-laki di Kroasia.

Hubungan antara Faktor Pengetahuan tentang VCT Waria dengan Kunjungan pelayanan VCT ulang

Proporsi waria yang melakukan kunjungan VCT ulang lebih banyak pada waria dengan pengetahuan tentang VCT cukup $(57,5 \%)$ dan baik $(51,3 \%)$ dibandingkan dengan yang kurang $(25,0 \%)$. Hal ini berarti bahwa waria sudah mempunyai pengetahuan yang cukup tentang VCT, terlihat dari hasil penelitian bahwa yang berpengathuan cukup 59,3\% sedangkan yang kurang hanya $11,9 \%$, sehingga dalam penelitian ini pengetahuan kurang dapat memberikan efek terhadap kunjungan VCT ulang pada waria.

Hasil uji statistik didapatkan tidak terdapat hubungan antara faktor pengetahuan tentang VCT waria dengan kunjungan pelayanan VCT ulang. Hasil ini berbeda dengan Tsegay, Edris dan Meseret (2013) dimana pengetahuan tentang VCT merupakan salah satu faktor yang berhbungan dengan pemanfaatan layanan VCT. Hasil penelitian juga berbeda dengan penelitian Yi et. al (2014) dimana pengetahuan cukup penting dalam keberhasilan program VCT, Pendidikan HIV adalah komponen utama program intervensi berbasis masyarakat di Kamboja yang mungkin efektif dalam meningkatkan akses terhadap pencegahan dan perawatan HIV pada VCT, layanan melalui kemitraan dengan jaringan MSM.

Hasil penelitian juga berbeda dengan penelitian Syahrir, Amiruddin dan Wahiduddin (2013) dimana 10 orang $(45,5 \%)$ dari 22 responden yang berpengetahuan tinggi dan memanfaatkan klinik VCT dengan baik. Hasil uji statistik diperoleh ada hubungan pengetahuan dengan pemanfaatan klinik VCT. Hasil penelitian juga tidak sejalan dengan Wang et.al. (2010) di China dan Charles et.al. (2009) di Tanzania, Lau et.al (2009) di Hongkong yang menunjukkan bahwa ada hubungan pengetahuan dengan pemanfaatan klinik VCT.

Hubungan antara Persepsi terhadap Pelayanan VCT Waria dengan Kunjungan pelayanan VCT ulang

Proporsi waria yang melakukan kunjungan VCT ulang lebih banyak pada waria dengan persepsi positif tentag pelayanan VCT $(67,6 \%)$ dibandingkan dengan yang negatif $(32,8 \%)$. Hal ini berarti bahwa semakin positif persepsi waria tentang pelayanan VCT maka akan semakin mendorong waria ulang melakukan kunjungan VCT ulang. 
Hasil uji statistik didapatkan terdapat hubungan antara persepsi terhadap pelayanan VCT waria dengan kunjungan pelayanan VCT ulang. Prinsip pelayanan VCT yaitu sukarela dalam melaksanakan testing HIV, saling mempercayai dan terjaminnya konfidensialitas, mempertahankan hubungan relasi konselor-klien yang efektif dan testing yang dilakukan VCT dinilai baik oleh waria sehingga mendorong waria untuk melakukan kunjungan VCT ulang. Hasil ini berbeda dengan penelitian Shrestha (2015) menemukkan bahwa persepsi tidak berhubungan dengan pemanfaatan layanan VCT, karakteristik predisposisi yang berhubungan dengan diantaranya adalah penerimaan keluarga, faktor kebutuhan, dan tersedianya layanan VCT. Hubungan antara Persepsi terhadap Perilaku Seksual yang dilakukan Waria dengan Kunjungan pelayanan VCT ulang

Proporsi waria yang melakukan kunjungan VCT ulang lebih banyak pada waria dengan persepsi positif tentag perilaku seksual yang dilakukan $(63,2 \%)$ dibandingkan dengan yang negatif $(37,3 \%)$. Hal ini berarti bahwa waria dengan persepsi positif lebih brpeluang untuk melakukan kunjungan VCT ulang dibadingkan dengan yang persepsinya negatif.

Hasil uji statistik didapatkan terdapat hubungan antara persepsi terhadap perilaku seksual yang dilakukan waria dengan kunjungan pelayanan VCT ulang. Perilaku seks berisiko pada waria disebabkan karena kebanyakan waria melakukan anal seks (hubungan seks dengan penetrasi ke dalam anus) pada pasangannya. Perilaku tersebut merupakan perilaku berisiko karena kemungkinan luka yang memudahkan terjadinya penularan IMS dan HIV. Selain anal seks, waria juga melakukan aktivitas oral seks. Aktivitas seksual yang mereka lakukan itu berisiko tinggi terhadap penularan IMS dan HIV/AIDS. Bahaya lain yang mengancam adalah apabila sperma pasangan seksual masuk ke mulut kelompok waria yang melakukan aktivitas tersebut terinfeksi HIV/AIDS. Hasil penelitian menunjukkan bahwa waria yang mempunyai persepsi positif 56,3\% lebih banyak dari yang persepsi negatif $43,7 \%$, ini menunjukkan bahwa waria telah menyadari bahwa perilaku seksual yang dilakukan selama ini merupakan perilaku yang berisiko terhadap penularan penyakit menulatr seksual dan HIV sehingga waria terdorong untuk melakukan kunjungan VCT ulang menginngat perilaku seksualnya yang berisiko.
Hasil penelitian mendukung penelitian Tsegay, Edris dan Meseret (2013) menemukkan bahwa salah satu faktor utama yang diidentifikasi untuk meningkatkan pemanfaatan layanan VCT adalah persepsi risiko yang lebih tinggi

\section{SIMPULAN}

Berdasarkan hasil penelitian dan pembahasan maka simpulan yang didapat bahwa karakteristik yang berhubungan dengan kunjungan pelayanan VCT ulang pada waria adalah riwayat infeksi, persepsi terhadap pelayanan VCT, persepsi terhadap perilaku seksual yang dilakukan dan dukungan kelompok. Sedangakan umur, pendidikan, sosial ekonomi, pengetahuan tentang VCT, dan dukungan keluarga tidak berhubungan dengan kunjungan pelayanan VCT ulang pada waria. Variabel yang bermakna dengan kunjungan pelayanan VCT ulang adalah variabel riwayat infeksi, persepsi terhadap pelayanan VCT, persepsi terhadap perilaku seksual yang dilakukan.

\section{REFERENSI}

Alemie \& Balcha. (2012). Vct clinic hiv burden and its link with hiv care clinic at the university of gondar hospital. Journal of BMC Public Health, 12: 1010.

American Psychological Association (APA). (2006). Answers to Your Questions About Transgender Individuals and Gender Identity. American Psychological Association. Washington DC. USA.

Andersen, Ronald \& Newman. (1973). Equity In Health : Empirical Analysis in Social Policy. London : Cambridge Mall Bailinger Publishing.

Banyard. (2002). Psychology in Practice : Health. Dorchester Typesetting Group Limited, Dorset, England. Printed in Great Britain for Hodder \& Stoughton Educational, a division of Hodder Headline Plc. 338 Euston Road, London NW1 3BH by The Bath Press Ltd.

Depkes. (2008). Pedoman Pelayanan Konseling dan Testing HIV/AIDS Secara Sukarela (Voluntary Counselling And Testing) Direktorat Jenderal Pengendalian Penyakit dan Penyehatan Lingkungan Jakarta. 
Lawrence, G.W. (1991). Health Promotion Planning An Educational and Environmental Approach. Mayfield Publishing Company. Mountain ViewToronto-London.

International AIDS Society. (2014). Men who have sex with men (MSM) - Factsheet.

Puljic et. Al. (2014). Repeat HIV Testing at Voluntary Testing and Counseling Centers in Croatia: Successful HIV Prevention or Failure to Modify Risk Behaviors. Plos One, 9:4, e93734.

Shrestha. (2015). Determinants of voluntary HIV counseling and testing (VCT) uptake among men who have sex with men (MSM) in Nepal. The Centre for International Health/Department of Global Public Health and Primary Care. University of Bergen.

STBP (2007). Surveilans Biologis Perilaku Terpadu Pada Kelompok Berisiko Tinggi di Indonesia 2007.

Tsegay. Edris\& Meseret. (2013). Assessment of voluntary counseling and testing service utilization and associated factors among Debre Markos University Students. North West Ethiopia: a cross-sectional survey in 2011. Bio Medic Central. Publick Health. 2013. 13:243.

UNAIDS. (2013). UNAIDS report on the global AIDS epidemic 2013. Joint United Nations Programme on HIV/AIDS (UNAIDS)

UNAIDS. WHO. (2008). Enabling effective voluntary counselling and testing for men who have sex with men. Increasing The Role Community Based Organizations in scaling up VCT Services for MSM in China. UN Technical Working Group on MSM and HIV/AIDS. Beijing China.

Voluntari Counselling Testing (VCT)2007. Aidsindonesia.or.id. <http://www.aidsindonesia.or.id>.

Wang et al. (2010). Factors Associated with Utilization of a Free HIV VCT Clinic by
Female Sex Workers in Jinan City, Northern China. AIDS Behav (2010) : 15 : 702 - 710. DOI 10.1007/s10461-0109703-2.

Widiyanto. (2008). Faktor-faktor yang Berhubungan dengan Praktik Wanita Pekerja Seks (WPS) dalam VCT Ulang di Lokalisasi Sunan Kuning Semarang. Tesis. Magister Promosi Kesehatan Program Pasca Sarjana Universitas Diponegoro Semarang. 